January 2015

\title{
New Perspectives on European Women's Legal History
}

Sara L. Kimble

DePaul University, skimble2@depaul.edu

Marion Rowekamp

Follow this and additional works at: https://via.library.depaul.edu/snl-faculty-pubs

Part of the European History Commons, European Law Commons, Family Law Commons, History of Gender Commons, Human Rights Law Commons, Law and Gender Commons, Legal Commons, Legal Profession Commons, Other History Commons, Other Legal Studies Commons, and the Women's History Commons

\section{Recommended Citation}

Kimble, Sara L. and Rowekamp, Marion. (2015) New Perspectives on European Women's Legal History. https://via.library.depaul.edu/snl-faculty-pubs/2

This Book is brought to you for free and open access by the School of Continuing and Professional Studies at Digital Commons@DePaul. It has been accepted for inclusion in School of Continuing and Professional Studies Faculty Publications by an authorized administrator of Digital Commons@DePaul. For more information, please contact digitalservices@depaul.edu. 
New Perspectives on European Women's Legal History

Routledge [ISBN: 978-1-13-880554-5]

Editors: Sara L. Kimble \& Marion Röwekamp

Chapter Abstracts

June 6, 2014

\section{Part I. Women in the Legal Professions \\ 1. Krassimira Daskalova, "Bulgarian Women in Legal Education and the Legal Profession during the First Half of Twentieth Century"}

This contribution presents the history of women in the juridical profession in Bulgaria during the first half of the twentieth century. The chapter first addresses the history of women's education in law from the establishment of the first Bulgarian University in 1888 and women's admittance in 1901. The second part follows the struggles of female law graduates who could not practice the profession before 1944. The third part explores case studies of female lawyers and women's rights leaders whose biographies illustrate the interconnection of the personal and the political. The chapter also explores the creation of women's solidarity groups, especially the development of the Bulgarian Association of University Women and the Bulgarian Women's Union and their impact on women's rights.

\section{Eva Schandevyl, "Women and the Courts in Belgium: an Historical Perspective"}

This chapter provides a broad survey of more than one hundred years of Belgian legal history in relation to women's access to the bar and to the judiciary. It investigates the barriers to women's emancipation and to gender equality and the feminist activism that challenges such opposition. Its central contribution is an analysis of the gendered nature of the arguments regarding women's rights to work as judges and the influence of the two world wars on women's professional and political rights, first as lawyers in 1922 and a generation later as voters and judges in 1948.

\section{Sara L. Kimble, "The Rise of 'Modern Portias': Female Lawyers and Activism in Modern France, 1888-1939"}

This chapter focuses on the political and historical significance of women's entrance into the legal profession in France during the French Third Republic. Using archival and historical documents and highlighting women's agency as historical actors, the chapter argues that women's participation in the legal profession had socio-political ramifications because a cadre of female lawyers engaged in public-interest advocacy and worked in solidarity with influential reform organizations. Their activism contributed to the dissemination of popular legal knowledge, strengthened the political movement for women's legal equality, and supported the development of the French juvenile court system.

\section{Mia Korpiola, "Attempting to Advocate: Women Entering the Legal Profession in Finland, 1885-1915"}

This chapter discusses the entry of Finnish women into advocacy in the late 1800s and early 1900s. In Finnish legal culture where lay advocacy was allowed and relatively common, several 
women (including Anna Åkesson and Signe Silén), engaged in de facto advocacy in this period. Despite the approbation of this situation by judges and lawyers, however, the emerging legal profession managed to oust all persons without a law degree from the field advocacy in 18961898. After this, female advocates seem to have disappeared for more than a decade until Agnes Lundell, who had taken exams at the Faculty of Law, was again tacitly accepted in the courtroom in 1909. Lundell practiced law but faced discrimination and was banned from the judiciary. This chapter illustrates the power of gender as it operated in Finland from 1885 to 1915.

\section{Marion Röwekamp, "Women, Equal Rights and the Legal Profession in Germany, 1895-1933"}

This chapter explores the struggles by German women to gain access to the legal professions, the arguments that they used, and the resistance that they encountered from defenders of the status quo. It argues that access was achieved belatedly compared to other academic professions because of issues related to legal study and the practice of law in Germany as well as to the fear that women in law would lead directly to women's suffrage and equality in other areas such as the family. It focuses on the development of female lawyers between 1922, the year of their access, and 1933, as well as on their participation in legal reform projects in the years of the Weimar Republic.

\section{Gordana Stojaković, "The First Lawyers and Attorneys: The Struggle for Professional Recognition of Women's Rights in Yugoslavia, 1918-1953"}

This chapter addresses the legal history of women's rights in Yugoslavia including their access to the legal profession and the struggle for women's rights. The survey is limited to the period from 1918-1953, which begins with the creation of the Kingdom of Serbs, Croats, and Slovens and ends with cessation of the Women's Antifascist Front of Yugoslavia in socialist Yugoslavia. This chapter focuses on the professional and personal choices of two attorneys Katarina Lengold-Marinković (1904-1974) and Neda Božinović (1917-2001) who were involved in feminist and communist women's organizations.

\section{Iwona Dadej, "'The Napoleonic Civil Code is to Blame for My Decision to Study Law': Female Law Students and Lawyers in the Second Polish Republic, 1918-1939"}

This chapter examines how a group of female Polish lawyers successfully fought for their right to study and practice law in the early decades of the twentieth century and describes the Warsaw School of Female Lawyers (Warschauer Juristinnen-Schule). By analyzing the source material of several feminist political organizations from the Second Polish Republic, this research reconstructs the knowledge about this profession, its aims and goals, as well as the women's fields of work and their engagement within the Polish women's movement. As female pioneers, these women suffered from being "invisible" both as women and as members of a traditionally male profession. This chapter offers a close analysis of the biographies of the female pioneers within the field of law as well as their leading role in academic institutions to better understand their status as female experts in the socio-political discourses and projects undertaken during the interwar years. 


\section{Part II. Gender And Family Law \\ 8. Melissa Feinberg, "Democracy at Home: Family and Marriage Law in Interwar Czechoslovakia"}

This chapter examines the failed attempt to create a unified Czechoslovak civil code during the interwar period. While the vast majority of Czechoslovaks enthusiastically supported women's suffrage, there was no similar consensus on the extent to which women should be made into men's equals in other legal realms. While feminists believed that family and marriage law should be completely egalitarian, Catholic women's rights activists argued that there were natural gender differences that should be reflected in civil law. Ultimately, however, the effort to revise the civil code foundered on Catholic opposition to mandatory civil marriage.

\section{Jana Osterkamp, "Equality at Stake: Legal and National Discourses on Family Law in Czechoslovakia"}

When Czechoslovakia granted constitutional and suffrage rights to women in 1918, it was among the vanguard nations in Europe in support of women's equality. However, in private family law, the traditional gap between women's legal position and that of men remained widely unchanged. Furthermore, the gap deepened due to the fact that the comparatively more liberal case law system in Slovakia, the former Hungarian part of the country, was ignored and misinterpreted as backward. This chapter focuses on attempts made by German legal scholars of constitutional and private law to bridge these inequalities at a critical moment in 1931 at the German Lawyer's Association meeting in Czechoslovakia. The legal debates on family law emphasized Czech and German legal thinking that resulted in the marginalization of Slovakian law to the detriment of family law reform.

\section{Evdoxios Doxiadis, "Adaptation, Emulation, or Tradition? Greek Family Law and the Courts in the First Decades of the Modern Greek State"}

This essay examines the impact of the establishment of the modern Greek state on family law and the way that law dealt with gender questions within the broader theoretical debates by early Greek legal scholars and the associated formation of the juridical system. The conclusion finds that Greece attempted to emulate European legal practices while maintaining its own legal traditions and thus ended up innovating and creating a legal system that paid lip service both to tradition and the European model while remaining distinct. Modern Greek law incorporated most preexisting legal rights for women in contrast to most European legal systems of the time, but the new legal structures removed women from the judicial process, increasing their dependency on men to protect their rights while social transformations adversely affected women's rights.

\section{Gloria Nielfa, "Family Law, Legal Reforms, Female Lawyers and Feminist Claims in Spain, 1868-1950}

This chapter analyzes the advances and setbacks in the situation of women with regard to family law in Spain between 1868 and 1950 and the process of the incorporation of women into the legal professions. This study documents the role of female lawyers in the feminist movement that underscores the importance of the Second Republic in the implementation of reforms. After analyzing the impact of the exceptional circumstances of the civil war, this chapter shows how 
the establishment of the Franco dictatorship resulted in the abolition of advances, and the return to centuries-old laws with regard to marriage, and the gradual closure of the professional opportunities open to women.

\section{Anne Cova, "Legal Position of Women in Portugal: The Case of the Standing Committee On Legislation of the National Council of Portuguese Women (CNMP), 1914-1947"}

This chapter approaches women in law in Portugal by looking at a feminist federation called the National Council of Portuguese Women (Conselho Nacional das Mulheres Portuguesas, CNMP), established in Lisbon in 1914. This organization emerged from the International Council of Women (ICW), which had been founded in Washington in 1888 "to stimulate the sentiment of internationalism among women throughout the world" as an attempt to build a collective women's identity. The CNMP was the longest surviving of all Portuguese women's organizations in the twentieth century and lasted until 1947 when it was abolished by the dictatorship. By analyzing the claims of the CNMP in the area of law and putting them in a comparative perspective, this chapter aims to contribute to a transnational history of feminisms.

\section{Part III. International Perspectives and Intersections}

\section{Anne Logan, "Feminism and Criminology in Britain, 1910-1950"}

This chapter argues that the approach of so-called "first-wave" feminists in England and Wales towards matters of crime and criminal justice during the 1920-50 period was based upon four related philosophical and epistemological pillars: feminism, humanitarianism, activism, and research. It rejects the notion that feminist activism in the decades after 1918 was entirely dominated by maternalist discourse, arguing instead that humanitarianism was a more significant philosophical underpinning of feminist campaigns on criminal justice in mid-twentieth century Britain. This argument is supported by evidence concerning the activism of feminists in support of reforming men's prisons, ending the death penalty in Britain, and in favor of international agreements on the treatment of prisoners. In these areas, female activists were obliged to undertake detailed research and policy analysis, inter alia establishing credentials as expert "criminologists," since these were matters in which their assumed, gendered "natural" expertise as women was largely irrelevant.

\section{Catherine Jacques, "International Feminist Lobby of the International Bodies: From the Nationality of the Married Woman to the Equality of Rights in the Family, 1919- 1970"}

This chapter examines the expansion of the feminist movement on the international level and its effort to secure equality within family law after the First World War. This chapter focuses on the debates surrounding the legal status of women and the project of the codification of international rights led first by the League of Nations and then put back on the agenda by the United Nations after 1945. These codification projects and the debates they engendered among officials and activists challenged the status quo on women's rights worldwide. These discussions, which spanned nearly fifty years, impacted the notion of gender equality and influenced the conceptualization of human rights. 


\section{Susan Zimmermann, "Night Work for White Women, Bonded Labour for Coloured Women? Contentious Traditions and the Globalization of Gender-specific Labour Protection and Legal Equality Politics, 1926 to 1939"}

This study analyses the political contention over internationalizing the policies of gendered labor standards between the ILO and a number of international women's organizations in the interwar period. As it explores the political struggle over women-specific night work prohibitions and the ILO's standards for forced labour and long term contract labour in the Southern hemisphere, the study posits two core arguments. First, the clash between legal equality and differential labor legislation is best understood as an uneasy negotiation between politics prioritizing the reduction of gender disadvantage versus politics aimed at curbing class and racial disadvantage. Second, divergent political visions regarding the integration of women into labour relations established in the pursuit of profit, together with related ideas about the individualization of women, formed a crucial point of reference in how diverse actors positioned themselves in relation to legal equality and differential labor legislation and the unequal globalization of labor standards.

\section{Regina Wecker, "Who Belongs" or The Question of Women's Citizenship in Switzerland since 1798"}

Since 1848, Swiss citizenship theoretically grants political rights to all individuals but the rules of naturalization and citizenship have not applied equally to women. The exclusion of women from political rights up to 1971 contributed to the construction of the "Swiss national character." The history of women's status under Swiss citizenship law complicates the notion of homogeneity and equality in Swiss national history. This chapter analyses the development of political citizenship and political rights as well as citizenship in the meaning of nationality and the connection, amalgamation, and disjunction between these concepts. 